IP Periodica Polytechnica

Chemical Engineering

59(1), pp. 96-103, 2015

DOI: $10.3311 /$ PPch. 7315

Creative Commons Attribution (i)

RESEARCH ARTICLE

\section{Film Coating as a New Approach to Prepare Tablets Containing Long-Term Stable Lactobacillus acidophilus}

\author{
István WAGNER ${ }^{1 *}$, Zsombor Kristóf NAGY ${ }^{1}$, Ágnes SUHAJDA², \\ Hajnalka PATAKI ${ }^{1}$, Péter SÓTI ${ }^{1}$, Tamás VIGH ${ }^{1}$, Attila BALOGH ${ }^{1}$, \\ Anna Helga HARASZTOS ${ }^{2}$, György MAROSI ${ }^{1}$
}

ReCEIVEd 31 JANUARY 2014; ACCEPTED AfTER REVISION 19 MAY 2014

\begin{abstract}
This work presents a study of film coating with the vaginal strain of Lactobacillus acidophilus, the aim of which was to dry the bacteria and manufacture probiotic tablets in one step and to enhance the survival rate of bacteria and their viability during storage. The results show that the film coated lactose-based tablets contained viable bacteria and the survival rate after the process was $21 \%$, which could be enhanced up to $59 \%$ by applying protective media (trehalose, sucrose, reconstituted skim milk (RSM)) during dehydration. Additionally, protective agents improved the viability of bacteria during storage too. After one year, $20 \%$ of the embedded bacteria were active when stored at $-20^{\circ} \mathrm{C}$, and viability dropped only one order of magnitude when stored at $7^{\circ} \mathrm{C}$. It was verified that the bacteria in film coated tablets were not sensitive to higher levels of humidity owing to the moisture-moderating polyvinyl alcohol-based coating composite. The described technology for production of tablets containing living bacteria by tablet coating seems industrially feasible as tablet film coaters are widespread in the pharmaceutical industry.
\end{abstract}

\section{Keywords}

film coating, probiotics, Lactobacillus acidophilus, bacterialis vaginosis, stability, vaginal tablet

\footnotetext{
${ }^{1}$ Department of Organic Chemistry and Technology, Faculty of Chemical Technology and Biotechnology, Budapest University of Technology and Economics, H-1521 Budapest, Hungary

${ }^{2}$ Department of Applied Biotechnology and Food Science, Faculty of Chemical Technology and Biotechnology, Budapest University of Technology and Economics, H-1521 Budapest, Hungary

* Corresponding author, e-mail: istvanwagner@gmail.com
}

\section{Introduction}

The consumption of probiotic products is expected to increase in following years owing to the wide range of positive effects associated with their application [1]. To guarantee the long term stability of probiotics, it is necessary to develop an optimal method for the dehydration of the probiotic suspension. Although the solidification of probiotic microorganisms can be considered to be widespread, there is still challenge in it because different kinds of stress (e.g. osmotic, thermal, mechanical etc.) can damage the cells during their conventional manufacturing [2]. Our aim was to develop an industrially feasible alternative way of solid formulation of bioproducts through the example of Lactobacillus acidophilus (LBA). This type of bacteria is one of the most widely investigated and applied species, especially in the field of dairy industry, and it is an important part of normal human bacterial flora located usually in mouth, in the gastrointestinal tract and in the urinary and genital tracts of females $[3,4]$. Bacterial vaginosis (BV) is a common infection caused by an imbalance of normal vaginal micro flora. This is in connection with the deficiency of Lactobacillus bacteria, which are replaced by undesirable exogenous microorganisms [5]. The treatment of this infection is a major challenge for healthcare as about one third of women are concerned (29\% in the United States [6]). Normally, a large number of Lactobacillus bacteria are present in vaginal microbiota that prevent the colonization and proliferation of pathogenic microorganisms through several ways, such as competition for nutrients and adherence, production of $\mathrm{H}_{2} \mathrm{O}_{2}$ [7], bacteriocins [8] and lactic acid (which is mainly responsible for the protective acidic $\mathrm{pH}$ of the vagina [9]). During BV the vaginal $\mathrm{pH}$ rises above 4.5 accompanied by the almost total disappearance of Lactobacillus bacteria [10]. The efficacy of standard antibiotic treatments has decreased (because of the spread of resistant bacteria strains and increasing refusal of antibiotics by the patients). Therefore, new, effective, readily accessible and economical lactobacilli-based probiotic therapies are badly needed. Intra-vaginal administration of Lactobacillus acidophilus has a better capability to cure $\mathrm{BV}$ compared to reference treatments, such as metronidazole 
tablet, estrogen cream, acetic acid jelly and tampon containing acetic acid or placebo [11, 12, 13]. Furthermore, a recent review drew attention to the increased importance of probiotic treatment for prevention of $\mathrm{BV}$, stating that more serious complications can be avoided this way [14].

Beside the emerging alternative technologies (e.g. electrospinning [15]), currently the most widely applied drying technology for solidification of fermented bacterial suspensions is freeze drying, because it takes place at low temperature, thus avoiding heat degradation. However, freeze drying also causes losses in cell viability through damaging of cell membranes by ice crystals. Uzunova-Doneva et al. showed that particularly the rate of freezing can determine the loss of viability of bacteria [16]. Furthermore, S. Rudy and C. Ratti pointed out another very important disadvantage of freeze drying, namely that it is time-consuming and has high energy demand $[17,18]$.

Another widespread drying technology is spray drying, where dry powder is made from suspensions by atomizing it in hot drying air. Temperature of inlet air is usually between 100 and $200^{\circ} \mathrm{C}$, which can cause serious heat damage in cells by degradation of ribosomes and other cellular structures [19]. Riveros et al. and Wang et al. spray dried Lactobacillus acidophilus under gentle conditions (inlet temperature: $100^{\circ} \mathrm{C}$, outlet temperature: $58^{\circ} \mathrm{C}, 60^{\circ} \mathrm{C}$ ). Nevertheless, survival rates were only $11 \%$ and $4.9 \%$ respectively [20, 21].

After the drying process, it is necessary to create a suitable formulation of dried bacteria. Tablets can provide easy administration, long-term stability and optimize the adhesion and colonization of bacteria to the epithelial mucosa by using appropriate excipients (e.g. lactose as nutrient for bacteria, polyvinyl pyrrolidone, polyvinyl alcohol as gelling agent etc.) [22].

The tablet dosage form has other advantages as well, such as good patient compliance, precise dosage, feasible large-scale production [23]. However, during tablet formulation the high compression force can cause a significant loss of viability due to mechanical damage of the bacteria [24], which means an additional decrease in activity. According to E. S. Chan et. al. [25], upper punch pressure between 90 and $180 \mathrm{MPa}$ causes $20 \%$ and $60 \%$ loss in the viability of bacteria. Further detrimental effect can be caused by the increased temperature induced by friction during tablet pressing. This increase in temperature is generally between 5 and $70^{\circ} \mathrm{C}$ and hot spots of $100^{\circ} \mathrm{C}$ are discussed [26, 27]. It means that bacteria potentially have to face temperatures over $60^{\circ} \mathrm{C}$, which is very harmful to the biomolecules (ribosomes, proteins, cell membrane lipids, DNA) of the bacteria and can cause considerable loss of cell viability [28].

It would be advantageous to manufacture tablets containing bacteria in a way that allows avoiding these harmful effects. Film coating of lactose-based (nutrition for LBA) tablets with bacteria-containing coating solutions can be a proper way to produce stable formulations with high bacteria content and at the same time avoid compression and attendant loss of viability.
Film coating is one of the oldest pharmaceutical processes, generally applied to protect the API, enhance mechanical integrity and modify release profile. Currently, the most commonly used coating device is the side-vented perforated pan coater, which enables very efficient drying and allows short coating times. Nowadays, more than $90 \%$ of tablets are film coated, and it can be achievable even as a continuous process, so it is an efficient and economical alternative of the currently known methods [29]. The aim of this work was to develop a method to produce lactose-based tablets with high bacteria content from fermented Lactobacillus acidophilus, avoiding the time- and energy-consuming freeze drying and the harmful tablet compression. We intended to investigate the possibility of solid formulation of LBA using film coating technology and the effect of different stabilizers on long term stability.

\section{Materials}

The model biodrug Lactobacillus acidophilus (Strain number: B1075) was kindly provided by National Collection of Agricultural and Industrial Microrganisms (Budapest, Hungary). The strain was stored at $7^{\circ} \mathrm{C}$ in MRS Agar (de Man, Rogosa and Sharpe Agar, LabM, UK). Placebo tablet cores were made from $\alpha$-lactose monohydrate (Tablettose 80, Meggle, Germany), colloid silicon dioxide (Aerosil 200, Evonik, Germany), magnesium stearate (Parchem, USA) and

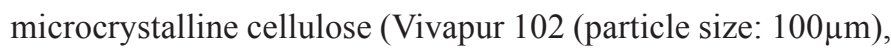
JRS Pharma, Germany). Tablets were coated by Opadry II clear (Colorcon, UK), PVA based water soluble coating. During fermentation and viability tests bacteria were cultured in MRS Broth and MRS Agar. Stabilizers were trehalose, reconstituted skimmed milk (RSM) and sucrose (Merck, Germany).

\section{Methods}

\subsection{Tablet compression}

The easy-to-apply oblong-shaped placebo tablets were compressed with Korsch (Germany) single punch tablet press from the mixture of $\alpha$-lactose monohydrate (Tablettose 80) (79.2 $\mathrm{m} / \mathrm{m} \%$ ) as diluent and nutrient for bacteria, colloid silicium dioxide (Aerosil 200) (0.4\%) as glidant, magnesium stearate $(0.4 \%)$ as lubricant and microcrystalline cellulose (Vivapur 102, particle size: $100 \mu \mathrm{m})(20 \%)$ as binder. The mass of tablets was $1 \mathrm{~g}$, the length, height and thickness of them were $19 \mathrm{~mm}$, $9 \mathrm{~mm}$ and $6 \mathrm{~mm}$ respectively.

\section{2 Preparing bacteria suspension}

Lactobacillus acidophilus was stored at $7^{\circ} \mathrm{C}$ on MRS Agar for long term storage. Three E-flask cultures of MRS broth were inoculated with LBA harvested from MRS Agar. Before the inoculation MRS Broth was freshly prepared and sterilized. According to the instructions of the manufacturer $55 \mathrm{~g}$ of MRS Broth powder was added to 11 of deionized water and after total dissolution it was autoclaved at $121^{\circ} \mathrm{C}$ for 30 minutes in 
the E-flasks. The fermentation was performed at $37^{\circ} \mathrm{C}$. After $48 \mathrm{~h}$ of fermentation, bacterial cells was harvested and centrifuged for 3 minutes with Heraeus Labofuge 400 R (Germany). Rotational speed was $4200 \mathrm{rpm}$.

\subsection{Freeze drying}

According to Zayed et. al. [30], sucrose (4 m/m\%), trehalose ( $4 \mathrm{~m} / \mathrm{m} \%$ ) and RSM (modified to $8 \mathrm{~m} / \mathrm{m} \%$ in order to prepare homogeneous film-coating suspension) were added to the centrifuged bacteria suspension ( $32 \mathrm{~g}$ ) as stabilizers [31, 32]. After total dissolution aliquots in sterile glass vials was frozen at $-20^{\circ} \mathrm{C}$ in a deep freezer for $2 \mathrm{~h}$, and then desiccated under vacuum ( $2 \mathrm{mbar}$ ) at $-3^{\circ} \mathrm{C}$ in the freeze-drier (Christ alpha $1-4$, Germany) for $24 \mathrm{~h}$. Three independent freeze drying processes were performed.

\subsection{Film coating}

The film coating was performed using a laboratory scale tablet coating machine (Glatt GC 250, Switzerland) equipped with a perforated rotating drum and Schlick bifluid spraying gun. $40 \mathrm{~g}$ of PVA-based Opadry II clear coating material was suspended in $200 \mathrm{ml}$ of dist. water by stirring (500 rpm). After 45 minutes the bacterial suspension was added to the coating suspension. The mass of bacterial suspension was $32 \mathrm{~g}$ without stabilizers and $38 \mathrm{~g}$ when it contained sucrose $(4 \mathrm{~m} / \mathrm{m} \%)$, trehalose $(4 \mathrm{~m} / \mathrm{m} \%)$ and RSM $(8 \mathrm{~m} / \mathrm{m} \%)$. The coating drum was filled with $800 \mathrm{~g}$ of lactose-based tablets and preheated with warm air (inlet air temperature was $45^{\circ} \mathrm{C}$ ). The amount of the consumed coating suspension was measured with a balance and it was sprayed at a speed of $9 \mathrm{~g} / \mathrm{min}$. The coating machine was equipped with one sprayer. The applied spraying pressure was 2.7 bar and the rotational speed of the drum was $20 \mathrm{rpm}$. Three independent film coating process were performed. Hardness of 20 coated and uncoated tablets was measured with a Schleuniger 4M hardness tester (Switzerland). Thickness of coating was measured on ten tablets by using the software of SEM.

\subsection{Scanning electron microscopy (SEM)}

Morphology of the film-coated tablets was investigated by a JEOL 6380LVa (JEOL, Japan) type scanning electron microscope. Each specimen was fixed by conductive double sided carbon adhesive tape and sputtered by gold (using JEOL 1200 instrument) in order to avoid electrostatic charging. Applied voltage was $15 \mathrm{kV}$. SEM image of suspension was taken of centrifuged bacteria suspension slushed onto the sample holder.

\subsection{Viability test}

In order to determine the number of colony forming units in the prepared freeze dried powder and in the tablets their weighted pieces (or one tablet in the case of tablets) were dissolved completely using $9 \mathrm{ml}$ of sterilized water (stock solution). Hereinafter these initial solutions were diluted in nine steps $(1$ step $=10$-fold dilution $)$ and after each step $1 \mathrm{ml}$ of solution was pipetted onto an MRS agar plate. Agar plates were kept in a lockup plastic box containing activated Microbiology Anaerocult ${ }^{\circledR}$ (Merck, Germany), which provided anaerobic circumstances by adsorbing oxygen. These were held at $37^{\circ} \mathrm{C}$ for 48 hours then the formed colonies were enumerated (colony forming unit $=\mathrm{CFU}$ ) and the viability was calculated. All the viability results presented in this paper are the mean values of three independent replicate assays. The relative standard deviations of these measurements were below $5 \%$.

\subsection{Storage test}

Samples containing LBA were kept in lockup containers at different temperatures (room temperature, $7^{\circ} \mathrm{C}$ and $-20^{\circ} \mathrm{C}$, which correspond to the temperatures of a freezer and a fridge respectively) in order to model everyday storage conditions. Furthermore, the effect of moisture content on the activity of bacteria was examined at $7^{\circ} \mathrm{C}$. One desiccator contained $\mathrm{P}_{2} \mathrm{O}_{5}$ (Merck, Germany), ensuring $0 \%$ relative humidity. A second one contained saturated aqueous $\mathrm{NaCl}$ (Merck, Germany) solution, providing $75 \%$ relative humidity. Viability of LBA bacteria in the samples was monitored in the storage period and CFU/g was determined. The applied method to determine cell viability was the plating procedure described in the Viability test part.

\subsection{Dissolution test}

In order to determine the release time of living LBA from film coated tablets, they were dissolved in $10 \mathrm{ml}$ of dist. water. Dissolution vessels were shaken with a speed of $50 \mathrm{rpm}$, temperature of dissolution media was $25^{\circ} \mathrm{C}$. After 1, 2, 3, 5, 10 and 20 minutes $1 \mathrm{ml}$ of the dissolution medium was diluted in eight steps ( 1 step $=10$-fold dilution) and after each step $1 \mathrm{ml}$ pipetted to MRS agar plate and the dissolution media was refilled with dist. water. The method of plating procedure was the same that was described above in this article. Dissolution was calculated as follows: the CFU number at different time points was divided by the total CFU number at the end of the dissolution test, which was considered as $100 \%$.

\section{Results and discussion}

The following results of formulation experiments served the evaluation of the performance of film coating technology in comparison with the conventional freeze drying process. Concerning the preparation of solid formulations containing bacteria, film coating is similar to spray drying; however, it provides much more gentle circumstances owing to lower drying temperature. Therefore film coating is suitable for the effective manufacturing of tablets containing bacteria even at large scale, owing to the easy scalability of the technology.

The first coating experiments served for optimizing the process parameters and providing reference tablets for the investigation of the effect of stabilizers (these were carried out without any stabilizer). 

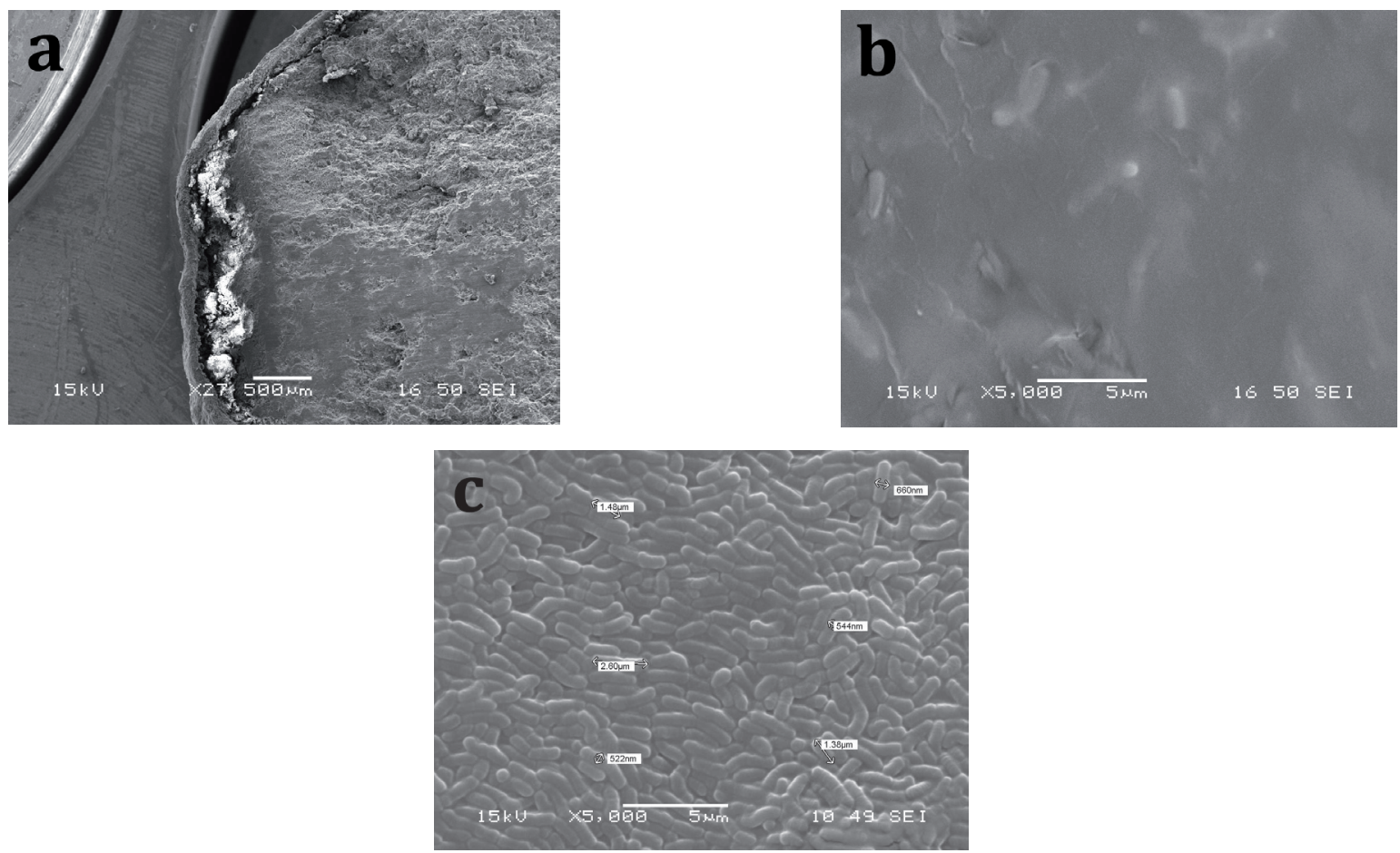

Fig. 1 Scanning electron micrographs of placebo tablets coated with LBA loaded coating polymer (a: cross-section , b: surface) and the suspension of LBA with thickness and length data (c)

\subsection{Film coating}

During film coating process $800 \mathrm{~g}$ placebo tablets were coated with polymer suspension containing bacteria. During the process average mass gain of tablets was around $4 \%$ and around $5 \%$ when the coating solution contained stabilizers. In each case three independent coating processes were performed.

The viscosity of the coating solution did not change significantly after the bacteria suspension had been added. Therefore, there was no need to increase the water content of the coating solution. During the coating process the outlet temperature did not exceed $38^{\circ} \mathrm{C}$; thus, the thermal damage of bacteria could be avoided. After the coating process, defects (e.g. twinning, capping, sticking, etc.) were not observed. Mechanical strength of uncoated tablets was $250 \mathrm{~N}$ and it was $161 \mathrm{~N}$ after the coating. This reduction was caused by the increased water content of tablet core, but it still means a good mechanical strength. After one year the average hardness of coated tablets was 155 $\mathrm{N}$ which means that the coated tablets have preserved their mechanical stability. Before the coating relative standard deviation of mass of tablet cores was $0.58 \%$ and it was $0.79 \%$ after the coating which meant that the film coating suspension was homogeneously distributed on the tablet cores.

Scanning electron microscopic studies were performed on the coated tablets to examine the coating layer containing LBA and the distribution of the bacteria in it. As illustrated by Fig. 1a, LBA loaded coating has continuous and uniform appearance (the damage under the coating originates from sample preparation).

The thickness of the formed film was about $140 \pm 10 \mu \mathrm{m}$. The SEM image with higher magnification reveals the bacteria in the coating layer (Fig. 1a). Their average sizes inside the film are similar to that of their original form (width: $\sim 0.5-0.7 \mu \mathrm{m}$; length: $\sim 1-3 \mu \mathrm{m}$ ) shown in Fig. 1c.

Table 1 shows the drying results of the film coating given as the average of three independent experiments. The coating suspension $(272 \mathrm{~g})$ contained $6.16 \times 10^{8} \mathrm{CFU}$. Since $40 \mathrm{~g}$ of the coating material was suspended in the solvent the CFU number related to dry matter content was $4.19 \times 10^{6} \mathrm{CFU} / \mathrm{mg}$. Average mass gain of tablets was $39 \mathrm{mg}$; thus, the theoretical maximum of bacteria content in tablets was $39 \times 4.19 \times 10^{6}=1.63 \times 10^{8}$. This calculation does not take into account the dry matter content of bacteria that would reduce the theoretical maximum of $\mathrm{CFU}$ and, simultaneously increase the survival rates presented in followings. Average bacteria content of tablets was $3.51 \times 10^{7}$ after the process, which means nearly $80 \%$ loss in the activity of bacteria relative to the theoretical maximum of bacteria content. This deactivation could only be caused by dehydration damage as heat damage was avoided during film coating by applying relatively low process temperature $\left(38^{\circ} \mathrm{C}\right)$, which is very gentle compared to spray drying [33]. During dehydration the removal of water results in an increase in the transition temperature associated with the liquid crystal to gel transition $\left(\mathrm{T}_{\mathrm{m}}\right.$, melting temperature) and causes detrimental effect on viability after rehydration, due to the potential leakage of cell membrane [34].

Some compounds such as trehalose, sucrose and reconstituted skimmed milk (RSM) can act as protective agents during drying, which were supposed to stabilize the cellular structures or act as a kind of physical shield moderating the heat and osmotic stresses [35]. 
Table 1 Average results of film coating processes

\begin{tabular}{ccc}
\hline & Film coating & Film coating with stabilizers \\
\hline $\begin{array}{c}\text { Coating suspension CFU/g } \\
\text { CFU number refers to } \mathbf{1} \mathbf{~ m g ~ o f ~ d r y ~}\end{array}$ & $6.16 \times 10^{8}$ & $1.96 \times 10^{8}$ \\
matter content of coating suspension & $4.19 \times 10^{6}$ & $1.18 \times 10^{6}$ \\
Mass gain per tablet (mg) & 39 & 50 \\
Theoretical maximum of CFU/tablet & $1.63 \times 10^{8}$ & $5.91 \times 10^{7}$ \\
CFU/tablet & $3.51 \times 10^{7}$ & $3.50 \times 10^{7}$ \\
Survival rate & $21 \%(\mathrm{RSD}: 10.0 \%)$ & $59 \%(\mathrm{RSD}: 5.9 \%)$ \\
\hline
\end{tabular}

Table 2 Results of freeze drying obtained in three independent experiments

\begin{tabular}{|c|c|}
\hline Initial suspension $\mathrm{CFU} / \mathrm{g}$ & $1.68 \times 10^{10}$ \\
\hline Average mass of freeze dried powder & $7.46 \mathrm{~g}$ \\
\hline $\begin{array}{c}\text { CFU number refers to } 1 \mathrm{mg} \text { of dry matter content of initial } \\
\text { suspension }\end{array}$ & $8.56 \times 10^{7}$ \\
\hline Number of CFU in $1 \mathrm{mg}$ of freeze dried powder & $5.31 \times 10^{7}$ \\
\hline Survival rate & $62 \%$ (RSD: $3.7 \%$ ) \\
\hline
\end{tabular}

Film coating was repeated using these protective carriers. In this case, the theoretical maximum of CFU in tablets was $5.91 \times 10^{7}$ because average mass gain of tablets was $50 \mathrm{mg}$. After the film coating one tablet contained $3.50 \times 10^{7}$ active bacteria which means that the survival rate of bacteria after coating was tripled (Table 1) by applying protective agents. Nearly $60 \%$ of theoretical maximum were still active after drying, which means great progress compared to spray drying.

In order to give a proper comparison between film coating and the most commonly used freeze drying, we investigated the effect of circumstances of freeze drying on the viability of LBA, applying the same protective carriers (Table 2). Results of freeze drying obtained in three independent experiments were as follows. The suspension $\left(38 \mathrm{~g}\right.$ ) contained $1.68 \times 10^{10} \mathrm{CFU}$ per $\mathrm{g}$ before freezing. After freeze drying average mass of freeze dried powder was $7.46 \mathrm{~g}$ and it contained $5.31 \times 10^{7} \mathrm{CFU}$ per $\mathrm{mg}$, which means $62 \%$ of initial bacteria survived the dehydration.

These results indicate that if appropriate stabilizers are applied, film coating can be a feasible solid formulation method of living LBA instead of freeze drying. Advantage of this process is the direct formation of administration-ready tablets. In contrast, freeze drying results in a powder containing bacteria that needs a final formulation step to obtain tablets accompanied with the possibility of viability loss due to mechanical and heat stresses. (Freeze dried tablets are also known, but their mechanical strength is very low, which makes their application unpractical, particularly in the case of BV.)

\subsection{Stability of bacteria in the solid dosage form}

It is well known that the drying technology has important effects not only on the viability of the solid bacteria but also on the long-term stability of them [32]. The change in the bacteria content in film coated tablets prepared without stabilizers is shown in Fig. 2. Survival rate of bacteria during the storage period was significantly a function of storage temperature. Room temperature had a huge detrimental effect; after 6 months there were no active bacteria alive in the product, which was predictable because marketed biopharmaceutical products containing living organism have to be stored generally at $2-8^{\circ} \mathrm{C}$. The curves of tablets stored at 7 and $-20^{\circ} \mathrm{C}$ are parallel and after one year they contained huge amount of active bacteria but the survival rate was still quite low, only $0.32 \%$ and $3.96 \%$ respectively.

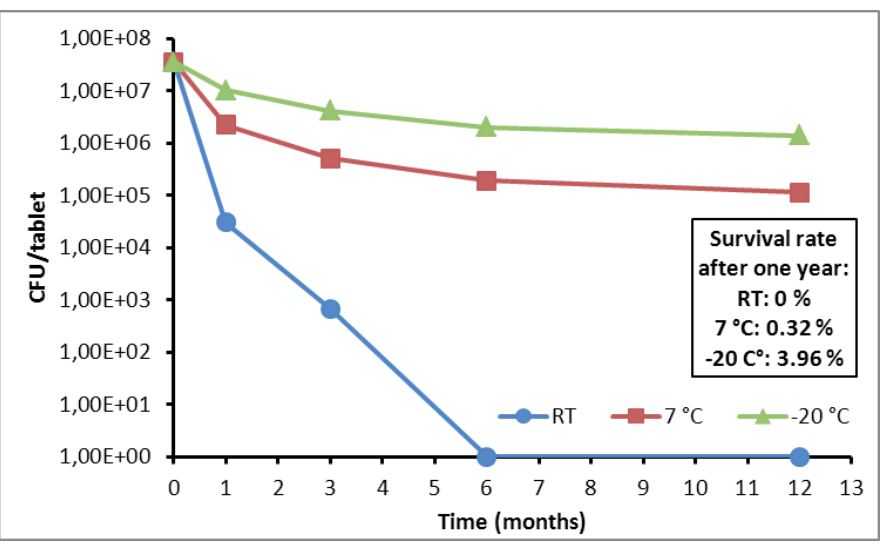

Fig. 2 Viability of bacteria in film coated tablets without stabilizers

Figure 3 shows the significantly improved stability of formulations in presence of stabilizers. Survival rate of bacteria after one year could be increased this way remarkably not only at $7^{\circ} \mathrm{C}(2.78 \%)$ and $-20^{\circ} \mathrm{C}(19.44 \%)$, but also at ambient temperature. 


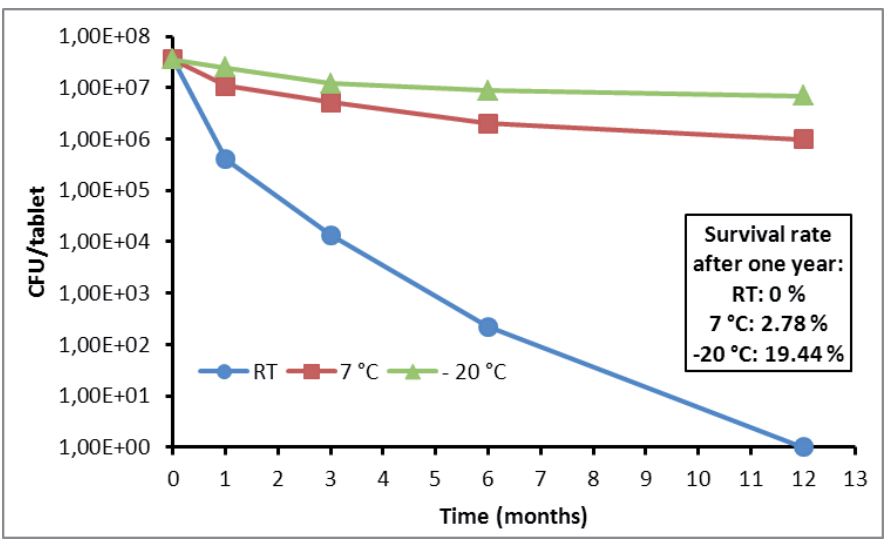

Fig. 3 Viability of bacteria in film coated tablets with stabilizers

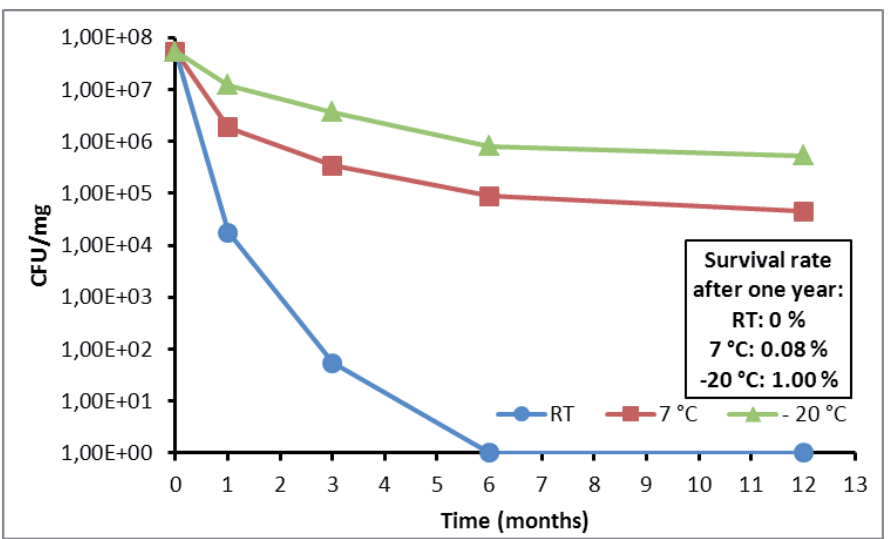

Fig. 4 Viability of freeze dried LBA during storage for 12 months in protective media at different temperatures

These remarkable results mean great progress compared to the stability of freeze dried bacteria. As it can be seen in Fig. 4 , despite of protective agents (sucrose, trehalose and reconstituted skimmed milk (RSM) the survival rate after a year was only $1 \%$ and $0.08 \%$ in the case of frozen $\left(-20^{\circ} \mathrm{C}\right)$ and chilled $\left(7^{\circ} \mathrm{C}\right)$ lyophilizates, and after six months all of the bacteria lost their activity at ambient temperature.

These results confirm the advantages of the film coating process in the formulation of probiotics. As it was described earlier this way of formulation provides less harsh conditions resulting in higher survival rate compared to spray drying [20, 21], furthermore, stability results showed that the produced tablets preserved higher rate of living bacteria than the freeze dried products after one year, owing to the relatively gentle conditions applied during coating and protective effect of the coating polymer.

\subsection{Effect of humidity on dried bacteria}

Another important factor of stability during storage is the moisture content. The results showed that desiccation of the freeze dried powder with $0 \%$ moisture content was required to achieve a positive effect on viability $\left(1.67 \times 10^{6} \mathrm{CFU} / \mathrm{mg}\right.$ after 12 weeks), while the $75 \%$ moisture level was detrimental $\left(4.25 \times 10^{5}\right.$ CFU/mg after 12 weeks) (Fig. 5). In contrast to this, not even a higher level of humidity caused significant decreasing in the

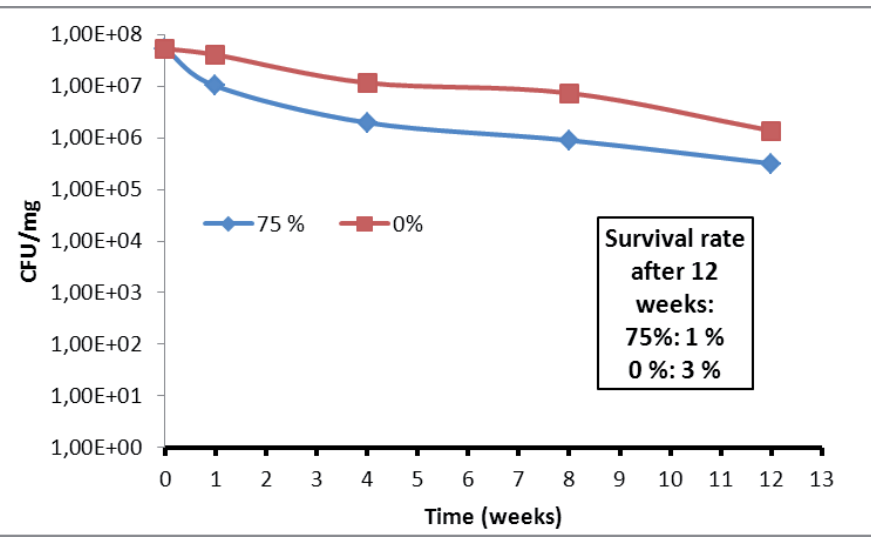

Fig. 5 Viability of freeze dried LBA with stabilizers during storage for 12 weeks at $7^{\circ} \mathrm{C}$ at different level of humidity

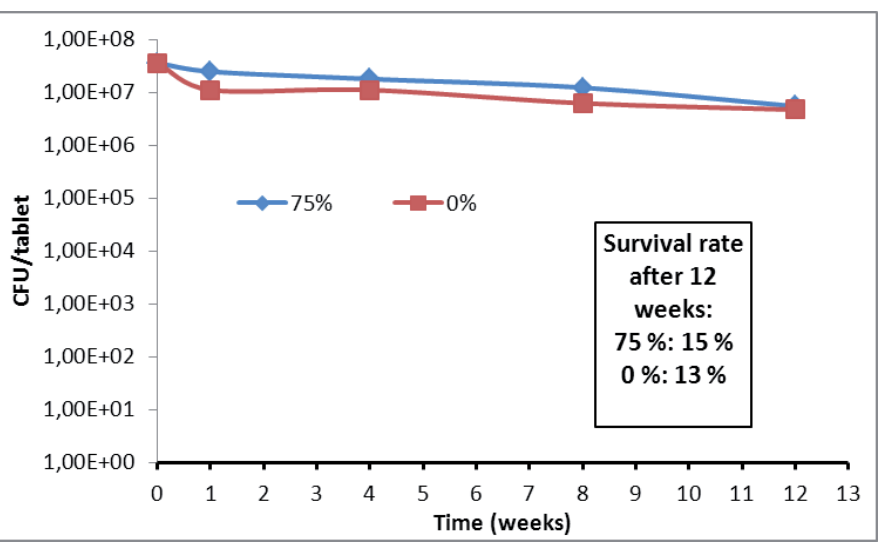

Fig. 6 Viability of LBA with stabilizers in film coating during storage for 12 weeks at $7^{\circ} \mathrm{C}$ at different level of humidity

case of tablets (Fig. 6), which is most likely a result of the PVAbased coating composite, which created a moisture moderating layer on the surface of the tablets. This means that bacteria formulated this way are more resistant to higher humidity and do not need special packaging and treatment.

\subsection{Dissolution test}

After disintegration the lactose content of the tablets acts as good nutrient for bacteria, so the prepared formulation could combine the advantages of pre- and probiotic pharmaceuticals during administration. Immediate release is very important for adequate efficiency; therefore, the release time of bacteria from the tablet was investigated. According to Fig. 7, the total amount of bacteria was released from the tablet within ten minutes, which, together with the lactose content of the tablets, can ensure a rapid proliferation immediately after administration.

\section{Conclusions}

Film coating performed with Lactobacillus acidophilus resulted in tablets containing living bacteria in one step. The survival rate of bacteria after the process was $21 \%$, but it could be enhanced to $59 \%$ by applying protective agents, which means great progress compared to spray drying. Furthermore, this result indicates that if appropriate stabilizers are applied, 


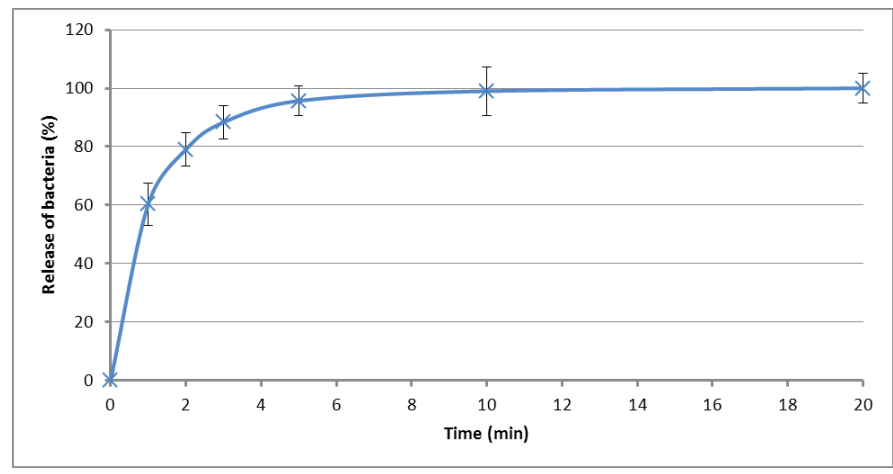

Fig. 7 Release time of LBA from film coated tablets

film coating can be an alternative solid formulation method for LBA instead of freeze drying (62\%), which could be more efficient, particularly if we take into consideration that after film coating there is no need further detrimental formulation steps. Stability results showed that the produced tablets contained higher amounts of living bacteria after one year than the freeze dried products, owing to the relatively gentle conditions applied during coating and the protective effect of the coating polymer, which has most likely an important role in the prevention of the detrimental effect of humidity by creating a moisture-moderating layer on the surface of the tablets. Embedded bacteria could be released immediately from the thin coating layer of the tablets containing lactose nutrient, which can promote rapid proliferation. This gentle drying technology can be applied for not only bacteria but other sensitive APIs for example herbal extracts [36, 37].

\section{Acknowledgements}

This project was supported by the New Széchenyi Plan (project ID: TÁMOP-4.2.1/B-09/1/KMR-2010-0002) and OTKA grant PD-108975. The authors would like to express their gratitude to Richter Gedeon Talentum foundation for their generous support of István Wagner’s scholarship.

\section{References}

[1] Quigley, E. "Probiotics in functional gastrointestinal disorders: what are the facts?" Current Opinion in Pharmacology. 8 (6). pp. 704-708. 2008. DOI: 10.1016/j.coph.2008.08.007

[2] Stadler, M., Viernstein, H. "Optimization of a formulation containing viable lactic acid bacteria." International Journal of Pharmaceutics. 256 (1-2). pp. 117-122. 2003.

DOI: 10.1016/s0378-5173(03)00068-1

[3] Cannon, J., Lee, T. A., Bolanos, J. T., Danziger, L. H. "Pathogenic relevance of Lactobacillus: a retrospective review of over 200 cases." European Journal of Clinical Microbiology \& Infectious Diseases. 24 (1). pp. 31-40. 2004. DOI: $10.1007 / \mathrm{s} 10096-004-1253-\mathrm{y}$

[4] Madigan, M. T., Martinko, J. M., Stahl, D., Clark, D. P. "Brock Biology of Microorganisms." Prentice Hall. 2006.

[5] Filho, D. S. C., Diniz, C. G., Da Silva, V. L. "Bacterial vaginosis: clinical, epidemiologic and microbiological features." HU Revista. 36 (3). pp. 223-230. 2010.
[6] Allsrth, J. E., Peipert, J. F. "Prevalence of bacterial vaginosis." Obstetrics \& Gynecology. 109 (1). pp. 114-20. 2007. DOI: 10.1097/01.AOG.0000247627.84791.91

[7] Mclean, N. W., Mcgrarty, J. A. "Growth inhibition of metronidazolesusceptible and metronidazole-resistant strains of Gardnerella vaginalis by Lactobacilli in vitro." Applied and Environmental Microbiology. 62 (3). pp. 1089-1092. 1996.

[8] Simoes, J. A., Aroutcheva, A., Heimler, I., Shott, S., Faro, S. "Bacteriocin susceptibility of Gardnerella vaginalis and its relationship to biotype, genotype, and metronidazole susceptibility." American Journal of Obstetrics and Gynecology. 185 (5). pp. 1186-1190. 2001. DOI: $10.1067 / \mathrm{mob} .2001 .118144$

[9] Falagas, M., Betsi, G., Althanasiou, S. "Probiotics for the treatment of women with bacterial vaginosis." Clinical Microbiology and Infection. 13 (7). pp. 657-664. 2007. DOI: $10.1111 /$ j.1469-0691.2007.01688.x

[10] Mastromarino, P., Macchia, S., Meggiorini, L., Trinchieri, V., Mosca, L., Perluigi, M., Midulla, C. "Effectiveness of Lactobacillus-containing vaginal tablets in the treatment of symptomatic bacterial vaginosis." Clinical microbiology and infection. 15 (1). pp. 67-74. 2009. DOI: 10.1111/j.1469-0691.2008.02112.x

[11] Neri, A., Sabah, G., Samra, Z. "Bacterial vaginosis in pregnancy treated with yogurt." Acta Obstetricia et Gynecologica Scandinavia. 72 (1). pp. 17-19. 1993. DOI: $10.3109 / 00016349309013342$

[12] Hallén, A., Jarstrand, C., Pahlson, C. "Treatment of bacterial vaginosis with Lactobacilli." Sexually Transmitted Diseases. 19 (3). pp. 146148. 1992.

DOI: 10.1097/00007435-199205000-00007

[13] Fredricsson, B., Englund, K., Weintraub, L., Ölund, A., Nord, C.-E. "Bacterial vaginosis is not a simple ecological disorder." Gynecologic and Obstetric Investigation. 28 (3). pp. 156-160. 1989. DOI: $10.1159 / 000293556$

[14] MacPhee, R. A., Hummelen, R., Bisanz, J. E., Miller, W. L., Reid, G. "Probiotic strategies for the treatment and prevention of bacterial vaginosis." Expert opinion on pharmacotherapy. 11 (18). pp. 2985-2995. 2010. DOI: $10.1517 / 14656566.2010 .512004$

[15] Nagy, Zs. K. "Nanofibrous solid dosage form of living bacteria prepared by electrospinning." Express Polymer Letters. 8 (5). pp. 352361. 2014.

DOI: $10.3144 /$ expresspolymlett.2014.39

[16] Uzunova-Doneva, T., Donev, T. "Influence of the freezing rate on the survival of strains Saccharomyces cerevisiae after cryogenic preservation." Journal of Culture Collections. 3. pp. 78-83. 2002.

[17] Ratti, C. "Hot air and freeze-drying of high-value foods: a review." Journal of Food Engineering. 49 (3). pp. 311-319. 2001 DOI: $10.1016 / \mathrm{S} 0260-8774(00) 00228-4$

[18] Rudy, S. "Energy consumption in the freeze- and cenvection-drying of garlic." TEKA Komisji Motoryzacji Energetyki Rolnictwa - OL PAN. 9. pp. 259-266. 2009.

[19] Aljarallah, K. M., Adams, M. R. "Mechanisms of heat inactivation in Salmonella serotype Typhimurium as affected by low water activity at different temperatures." Journal of Applied Microbiology. 102 (1). pp. 153-160. 2007 DOI: 10.1111/j.1365-2672.2006.03054.x

[20] Riveros, B., Ferrer, J., Borquez, R. "Spray drying of a vaginal probiotic strain of Lactobacillus acidophilus." Drying Technology. 27 (1). pp. 123-132. 2009.

DOI: $10.1080 / 07373930802566002$ 
[21] Wang, Y-C., Yu, R-C., Chou, C. C. "Viability of lactic acid bacteria and bifidobacteria in fermented soymilk after drying, subsequent rehydration and storage." International Journal of Food Microbiology. 93 (2). pp. 209-217. 2004.

DOI: 10.1016/j.ijfoodmicro.2003.12.001

[22] Maggi, L., Mastromarino, P., Macchia, S., Brigidi, P., Pirovano, F., Matteuzzi, D., Conte, U. "Technological and biological evaluation of tablets containing different strains of lactobacilli for vaginal administration." European Journal of Pharmaceutics and Biopharmarmaceutics. 50 (3). pp. 389-395. 2000.

DOI: 10.1016/S0939-6411(00)00121-1

[23] Sousa, J. P., Sousa, S. C., Costa, P., Cerdeira, E., Amaral, M. H., Sousa Lobo, J., Gomes, A. M., Pintado, M. M., Rodrigues, D., Rocha-Santos, T., Freitas, A. C. "Development of Probiotic Tablets Using Microparticles: Viability Studies and Stability Studies." AAPS PharmSciTech. 14 (1). pp. 121-127. 2012.

DOI: $10.1208 / \mathrm{s} 12249-012-9898-9$

[24] Blair, T. C., Buckton, G., Bloomfield, S. F. "On the mechanism of kill of microbial contaminants during tablet compression." International Journal of Pharmaceutics. 72 (2). pp. 111-115. 1991. DOI: 10.1016/0378-5173(91)90048-s

[25] Bowden, F. P., Tabor, D. "Reibung und Schmierung fester Körper." Springer Verlag. 1959.

[26] Picker-Freyer, K. M., Schmidt, A. G. "Does temperature increase induced by tableting contribute to tablet quality?" Journal of Thermal Analysis and Calorimetry. 77 (2). pp. 531-539. 2004.

DOI: 10.1023/B:JTAN.0000038992.42788.f7

[27] Teixeira, P., Castro, H., Mohácsi-Farkas, C., Kirby, R. "Identification of sites of injury in Lactobacillus bulgaricus during heat stress." Journal of Applied Microbiology. 83 (2). pp. 219-226. 1997.

DOI: 10.1046/j.1365-2672.1997.00221.x
[28] Suzzi, D., Toschkoff, G., Radl, S., Machold, D., Fraser, S. D., Glasser, B. J., Khinast, J. G. "DEM simulation of continuous tablet coating: Effects of tablet shape and fill level on inter-tablet coating variability." Chemical Engineering Science. 69 (1). pp. 107-121. 2012.

DOI: 10.1016/j.ces.2011.10.009

[29] Lievense, L. C., Verbreek, M. A. M., Noomen, A., van't Riet, K. "Mechanism of dehydration inactivation of Lactobacillus plantarum." Applied Microbiology and Biotechnology. 41 (1). pp. 90-94. 1994. DOI: 10.1007/BF00166087

[30] Crowe, J. H., Carpenter, J. F., Crowe, L. M. "The role of vitrification in anhydrobiosis." Annual Review of Physiology. 60. pp. 73-103. 1998. DOI: 10.1146/annurev.physiol.60.1.73

[31] Fu, N., Chen, X. D. "Towards a maximal cell survival in convective thermal drying processes." Food Research International. 44 (5). pp. 1127-1149. 2011

DOI: $10.1016 /$ j.foodres.2011.03.053

[32] Popovic, V., Heyerick, A., Petrović, S., Van Calenbergh, S., Karalic, I., Niketić, M., Deforce, D. "Cytotoxic Activity of Laserpitium latifolium L. Extract and Its Daucane and Phenylpropanoid Constituents." Records of Natural Products. 7 (3). pp. 245-249. 2013.

[33] Popovic, V., Heyerick, A., Petrović, S., Van Calenbergh, S., Karalić, I., Niketić, M., Deforce, D. "Sesquiterpene lactones from the extracts of two Balkan endemic Laserpitium species and their cytotoxic activity." Phytochemistry. 87. pp. 102-111. 2013.

DOI: $10.1016 /$ j.phytochem.2012.11.011 